Research Article

\title{
Pathogenicity of Meloidogyne incognita and Fusarium oxysporum f. sp. vasinfectum on Growth and Yield of Two Okra Varieties Cultivated in Ghana
}

\author{
Samuel Y. Agbaglo, Seloame T. Nyaku (D, Hannah D. Vigbedor, and Eric W. Cornelius \\ Department of Crop Science, College of Basic and Applied Sciences, University of Ghana, P.O. Box LG 44, Legon-Accra, Ghana \\ Correspondence should be addressed to Seloame T. Nyaku; stnyaku@ug.edu.gh
}

Received 15 April 2020; Revised 12 June 2020; Accepted 16 June 2020; Published 25 July 2020

Academic Editor: Maria Serrano

Copyright (c) 2020 Samuel Y. Agbaglo et al. This is an open access article distributed under the Creative Commons Attribution License, which permits unrestricted use, distribution, and reproduction in any medium, provided the original work is properly cited.

\begin{abstract}
The interaction of the fungus, Fusarium oxysporum f. sp. vasinfectum (FOV), and the nematode, Meloidogyne incognita, on wilt disease on "Essoumtem" and Clemson spineless okra varieties, was examined in pot and field experiments from September 2016 to June 2017, in the University of Ghana farms. Four-week-old "Essoumtem" and Clemson spineless seedlings for pot experiment and one-week-old "Essoumtem" and Clemson spineless seedlings for field experiment were inoculated with fungus, Fusarium oxysporum, and nematode, Meloidogyne incognita. The individual, simultaneous, and sequential inoculation of second stage juveniles (at $1000 \mathrm{~J}^{2} / \mathrm{kg}$ soil) of Meloidogyne incognita and Fusarium oxysporum $\left(1.1 \times 10^{6} \mathrm{cells} / \mathrm{kg}\right.$ soil) resulted in significant reduced plant growth parameters (plant height, plant girth, chlorophyll content, fresh and dry shoot weights, and fresh and dry root weights). Maximum suppression in plant growth parameters was observed in plants that received NF21 (Fusarium oxysporum inoculated 21 days after Meloidogyne incognita on okra) and F21 (fungus inoculated 21 days after seedling emergence) treatments for pot and field experiments, respectively. The least suppression of plant growth parameters was observed in separate inoculations of the two pathogens for both pot and field experiments. Maximum suppression in yield parameters was observed in okra plants that received NF21 and F21 treatments for pot and field experiments, respectively. Minimal yield suppression was observed for individual inoculations ( $N$ and $F$ treatments) in both pot and field experiments. The highest severity of wilt disease was observed on okra plants that received NF21 and F21 treatment in both pot and field experiments. Plants in control plots had higher yields and the least wilt incidences $(0.0 \%)$.
\end{abstract}

\section{Introduction}

Okra (Abelmoschus esculentus) is regarded, amongst other species of plants from the Malvaceae family, as extensively consumed [1] and equally known to be an economically significant vegetable crop cultivated in many parts of the world [1-4]. Hibiscus was the genus into which okra was categorized, and later, classifications reassigned it under Abelmoschus and differentiated it with copious features from the genus Hibiscus [5]. In Northern Ghana, the crop is grown for its high commercial value for deprived growers and significance as a component in the diet of the people. Within developing countries such as Ghana, okra is cultivated with ease, and it represents an essential cash crop for families in underprivileged areas. In Ghana, production levels and yield of okra in 2018 were 74,027 tonnes and $219,992 \mathrm{hg} / \mathrm{ha}$, respectively [6]. This crop's economic importance cannot be overemphasized as it contains food nutrients such as proteins, calcium, vitamins $\mathrm{C}$, and carbohydrates in larger quantities [7-11]. Meloidogyne incognita causes root-knot diseases infecting a wide range of crops [12-18]. Root-knot infections cause surge in incidence and severity of wilt diseases caused by bacteria and fungi [19]. Fusarium wilt (Vascular wilt) caused by the fungus Fusarium oxysporum f. sp. vasinfectum (FOV) is one of the utmost significant diseases on Malvaceae species [20]. The concept of nematode-fungi relationship in plant diseases has been researched for the mechanism of interaction to be 
understood [21-24]. The objective of this study was to evaluate individual, simultaneous, and sequential inoculations between Meloidogyne incognita and Fusarium oxysporum f. sp. vasinfectum on the growth and yield of "Essoumtem" and Clemson spineless okra varieties.

\section{Materials and Method}

2.1. Experimental Site. Both pot and field experiments were carried out in the University of Ghana Farm, Legon. The experimental site had a mean rainfall of $55 \mathrm{~mm}$, a mean temperature of $32.3^{\circ} \mathrm{C}$, and a relative humidity of $78 \%$ from September 2016 to January 2017, during the potting experimentation. The mean rainfall, temperature, and relative humidity from March 2017 to June 2017 were $56 \mathrm{~mm}$, $32.5^{\circ} \mathrm{C}$, and $69 \%$, respectively, for the field experiment. The soils at the site are classified under the Adentan series and are relatively light clayey soils with low fertility.

\subsection{Nematode Inoculum Preparation. Meloidogyne incognita} eggs were extracted from roots of infested okra plants. These eggs were hatched into second stage juveniles [25]. The second stage nematode juveniles for inoculations onto each plant were estimated to a concentration of 1,000 juveniles.

2.3. Fusarium Inoculum Preparation. Two-week-old culture was scraped into a beaker with sterile distilled water and blended. Sterile distilled water was added to obtain $1000 \mathrm{~cm}^{3}$ of the suspension. The fungal spore suspension (approximately $1.1 \times 10^{6}$ cells per $5 \mathrm{~mL}$ ) was calculated using a haemocytometer [26]. This concentration was inoculated per plant.

2.4. Pot Experiment. Two (2) varieties of okra, "Essoumtem" and "Clemson spineless", were used in this experiment. The soil (light loamy soil) for the pot experiments was sterilized at $105^{\circ} \mathrm{C}$ for three days and left overnight to cool. It was then used to fill plastic pots ( $5 \mathrm{~kg}$ of the sterilized soil per pot) with drainage holes at the base. The experiment was a $2 \times 7$ factorial laid out in a completely randomized design (CRD) with three replications. An experimental plot measured $2 \mathrm{~m}$ by $1.2 \mathrm{~m}\left(2.4 \mathrm{~m}^{2}\right)$. Alleys between the blocks were $1 \mathrm{~m}$, while that between the plots was $50 \mathrm{~cm}$. A total of 42 plots were used, and each plot had 15 okra plants with a planting distance of $60 \mathrm{~cm} \times 70 \mathrm{~cm}$. Five plants were tagged as record plants. Each block or replication had 14 plots. The treatments used for the pot experiment were as follows:

$F=$ okra plants inoculated with Fusarium oxysporum only

$N=$ okra plants inoculated with Meloidogyne incognita only

$\mathrm{NF}=$ Meloidogyne incognita and Fusarium oxysporum inoculated simultaneously on okra

NF7 = Fusarium oxysporum inoculated 7 days after Meloidogyne incognita on okra
NF14 = Fusarium oxysporum inoculated 14 days after Meloidogyne incognita on okra

NF21 = Fusarium oxysporum inoculated 21 days after Meloidogyne incognita on okra

$C=$ okra plants with neither Meloidogyne incognita nor Fusarium oxysporum inoculation (control)

Plant height, plant girth, and chlorophyll contents were taken at 4, 6, 8, and 10 weeks after planting okra for both pot and field experiments. The yield as well as data on biomass (fresh and dry shoot and root weight) were taken at the end of the experiment. The chlorophyll content index (CCI) was measured using a MC-100 chlorophyll concentration meter (Apogee Instruments, North Logan, USA).

2.5. Field Experiment. Planting was done on already infested nematode field. Soil samples were collected from each plot for nematode estimations before okra seeds were planted. The experiment was a $2 \times 4$ factorial treatment, arranged in a randomized complete block design (RCBD), with three replications. Each experimental plot measured $2.8 \mathrm{~m}$ by $2.5 \mathrm{~m}\left(7 \mathrm{~m}^{2}\right)$. Alleys between the blocks were $1 \mathrm{~m}$, while that between the plots of the same replication was $50 \mathrm{~cm}$. A total of 24 plots were used, and each plot consisted of 30 plants spaced in $50 \mathrm{~cm} \times 70 \mathrm{~cm}$ apart. Five plants were used within the plot as record plants. Each block or replication is made up of 8 plots. The treatments used were as follows:

$F 7=$ Fusarium oxysporum inoculated 7 days after okra seedling emergence in Meloidogyne incognita-infested field

$F 14=$ Fusarium oxysporum inoculated 14 days after okra seedling emergence in Meloidogyne incognitainfested field

F21 = Fusarium oxysporum inoculated 21 days after okra seedling emergence in Meloidogyne incognitainfested field

$C=$ uninoculated field (control)

2.6. Wilt Incidence and Severity. To determine the wilt incidence, a wilt incidence scale by Nene et al. [27] was used with wilt percentage and wilt severity computed as follows:

$$
\text { wilt incidence }(\%)=\frac{\text { number of plants wilted }}{\text { total number of plants }} \times 100 \text {, }
$$

wilt severity $(\%)=$

$\frac{\text { sum }(\text { rating number } \times \text { number of plants in the rating })}{\text { total number of plants } \times \text { highest rating }} \times 100 \%$.

2.7. Statistical Analysis. All agronomic parameters (plant height and plant girth), chlorophyll content, yield, and plant biomass contents were subjected to the analysis of variance (ANOVA), using Genstat 12th edition software [28], and 
significant means were separated, using a least significant difference (LSD) at $5 \%$.

\section{Results}

\subsection{Pot Experiment}

3.1.1. Mean Plant Height, Girth, and Chlorophyll Contents of "Essoumtem" and "Clemson Spineless" Plants Inoculated with Fusarium oxysporum in Pot Experiment from Weeks 4 to 10. There was a steady increase in plant height in Essoumtem (V1a) okra plants up to week 8. Inoculation of the treatments, NF14 and NF21, resulted in the least plant height $(43.0 \mathrm{~cm})$. The highest plant height $(54.0 \mathrm{~cm})$ was observed in control plants (Figure 1). In Clemson spineless (V2a), plant height increased steadily from week 4,6 , and 8 , and afterward growth was retarded until week 10; this was, however, not observed in the uninoculated Clemson spineless plants $(62 \mathrm{~cm})$, which had the highest plant height. Inoculation of the treatment, NF21, resulted in the least plant height $(44 \mathrm{~cm})$ followed by simultaneous inoculation of the fungus and nematode $(47 \mathrm{~cm})$ on plants (Figure 1).

There were significant differences $(P<0.05)$ in plant girth among the treatments for week 10 in Essoumtem (V1b) okra plants. Nematode (M. incognita) and fungus (FOV) decreased plant girth except in uninoculated plants. Plants that received NF14 have the least plant girth $(7.7 \mathrm{~cm})$, and the highest plant girth $(11.3 \mathrm{~cm})$ was observed in uninoculated plants (Figure 1). There was significant increase in plant girth in Clemson spineless (V2b) okra plants in all the treatments from week 4,6 , and 8 . These increases reduced towards the $10^{\text {th }}$ week except in plants that were not inoculated $(11.9 \mathrm{~cm})$. The least plant girth $(6.8 \mathrm{~cm})$ was observed in plants inoculated with fungus 21 days after nematode inoculation (Figure 1).

There were significant differences in chlorophyll content in Essoumtem (V1c) okra plants $(P<0.05)$ among the treatments. $M$. incognita and $F$. oxysporum infection decreased chlorophyll content of the plants. Plants that received NF7 treatments showed the least chlorophyll content (35.3 CCI). The highest chlorophyll content (50.3 CCI) was observed in the control (Figure 1).

There were significant differences in various treatments applied to Clemson spineless (V2c) okra plants. The least chlorophyll content (31.7 CCI) was observed in plants inoculated with NF21 treatment. Uninoculated plants were observed to show the highest chlorophyll content (49.4 CCI) (Figure 1).

3.1.2. Fresh and Dry Shoot Weight of "Essoumtem" and "Clemson Spineless" (Pot Experiment). There were significant differences $(P<0.05)$ with respect to fresh shoot weight of okra among treatments in Essoumtem and Clemson spineless okra plants. In Essoumtem, the total fresh shoot weights of plants inoculated with two pathogens were lower compared to uninoculated plants. Plants that received NF21 treatment were significantly different $(P<0.05)$ from the other treatments, for fresh shoot weight $(767 \mathrm{~g})$. Plants that received $F, N, N F$, and NF7 were not significantly different from each other. The highest fresh shoot weight $(1.554 \mathrm{~g})$ was in plants in control plots (Table 1). In Clemson spineless, fresh shoot weight was significantly lower $(593 \mathrm{~g})(P<0.05)$ in plants that received NF21. Plants that received $F, N, N F$, and NF7 were not significantly different from each other. The highest fresh shoot weight $(1,273 \mathrm{~g})$, however, was observed in plants in control plots (Table 1). The highest percentage reductions (50.6\% and 53.4\%) in fresh shoot weight of okra were observed in plants that received NF21 treatment for Essoumtem and Clemson spineless, respectively. The least percentage reductions (12.9\% and $17.7 \%$ ) for plants receiving $\mathrm{N}$ treatment were observed on Essoumtem and Clemson spineless okra plants, respectively (Table 1).

Significant differences $(P<0.05)$ existed for dry shoot weight within Essoumtem variety. Plants that received NF21 treatments had the least dry shoot weight $(471 \mathrm{~g})$. Plants that received N, NF, and NF7 treatments were not significantly different from each other. The highest dry shoot weight $(1,210 \mathrm{~g})$ was observed in control plants (Table 1$)$. Significant differences $(P<0.05)$ also existed for dry shoot weight within the Clemson spineless okra variety. Plants that received NF21 had the least dry shoot weight $(329 \mathrm{~g})$. Plants that received N, NF, and NF7 treatments were not significantly different from each other. The highest dry shoot weight $(973 \mathrm{~g})$ was observed in plants in control plots (Table 1). The highest percentage reductions in dry shoot weight of okra (61.1\% and 66.2\%) were observed in plants that received NF21 treatment for Essoumtem and Clemson spineless, respectively. The least percentage reductions $(7.5 \%$ and $32.1 \%$ ) were observed for Essoumtem plants that received $N$ treatments and Clemson spineless plants that received NF7 treatment, respectively. Control plants did not show any reduction in dry shoot weight (Table 1).

3.1.3. Fresh and Dry Root Weights of "Essoumtem" and "Clemson Spineless" (Pot Experiment). There were significant differences $(P<0.05)$ in fresh root weight among different treatments within Essoumtem and Clemson spineless okra plants (Table 2). Appreciable levels of reductions were observed in plants inoculated individually and sequentially with both nematode and fungal pathogens in Essoumtem. However, plants that received the NF21 treatment had the least (221 g) fresh shoot weight. Plants that received $F, N, N F$, NF7, and NF14 treatments did not significantly differ from each other for fresh root weight. The highest fresh root weight $(727 \mathrm{~g})$, however, was observed in control plants. Within Clemson spineless plants, those that received the NF21 treatment had the least fresh root weight $(300 \mathrm{~g})$. Plants that received $F, N, \mathrm{NF}, \mathrm{NF} 7$, and NF14 treatments did not significantly differ from each other. The highest fresh root weight $(628 \mathrm{~g})$ was observed in control plants. The highest percentage reductions $(69.6 \%$ and $52.2 \%)$ in fresh root weight of okra were observed in Essoumtem and Clemson spineless plants that received NF21 treatment, respectively. The least percentage reductions $(15.4 \%$ and 20.0\%) were observed for Essoumtem plants that received NF treatment and Clemson spineless plants that received $\mathrm{F}$ treatment, respectively (Table 2 ). 
$\mathrm{V} 1 \mathrm{~b}$

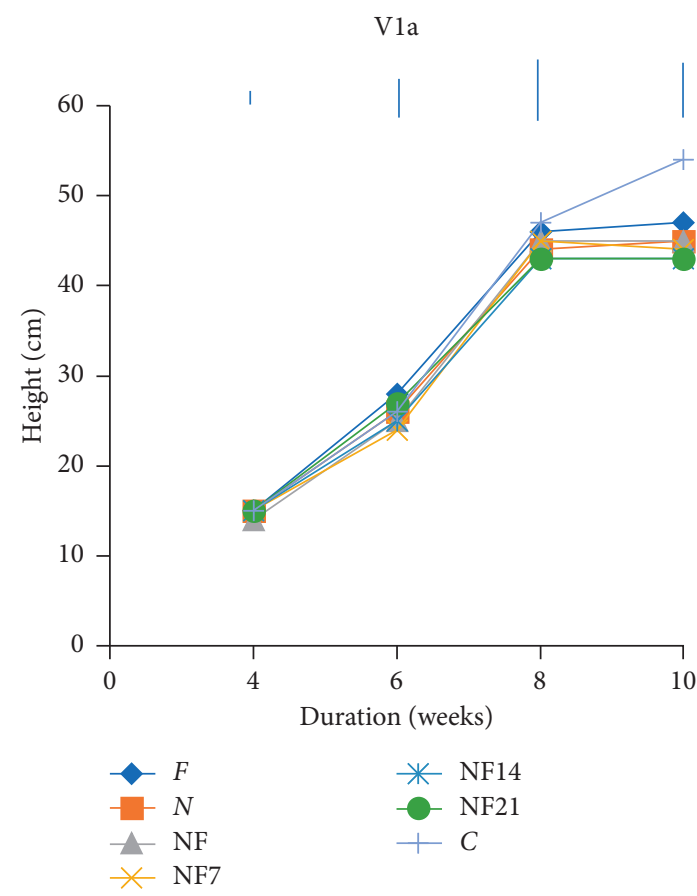

(a)

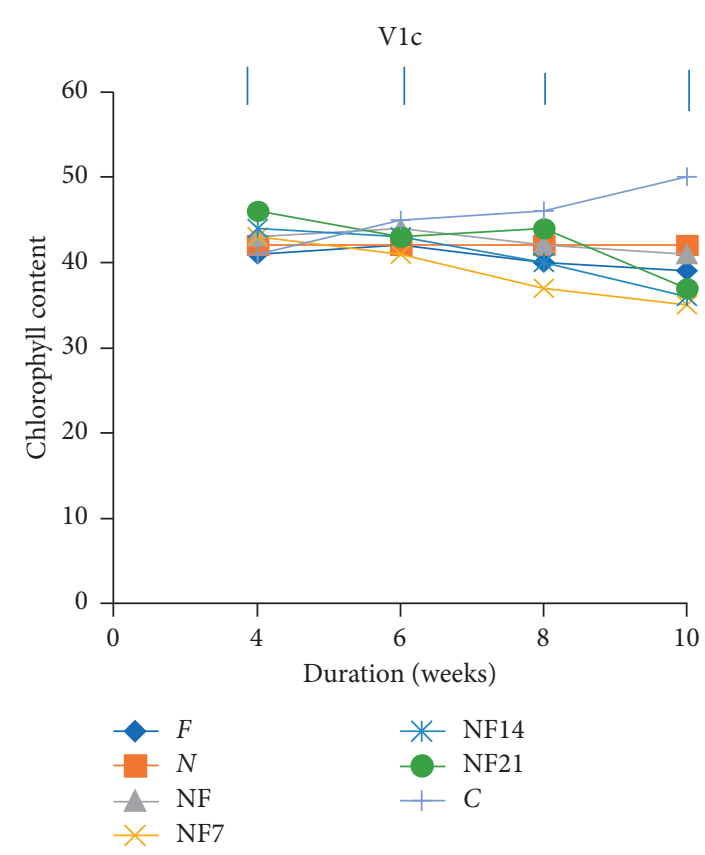

(c)

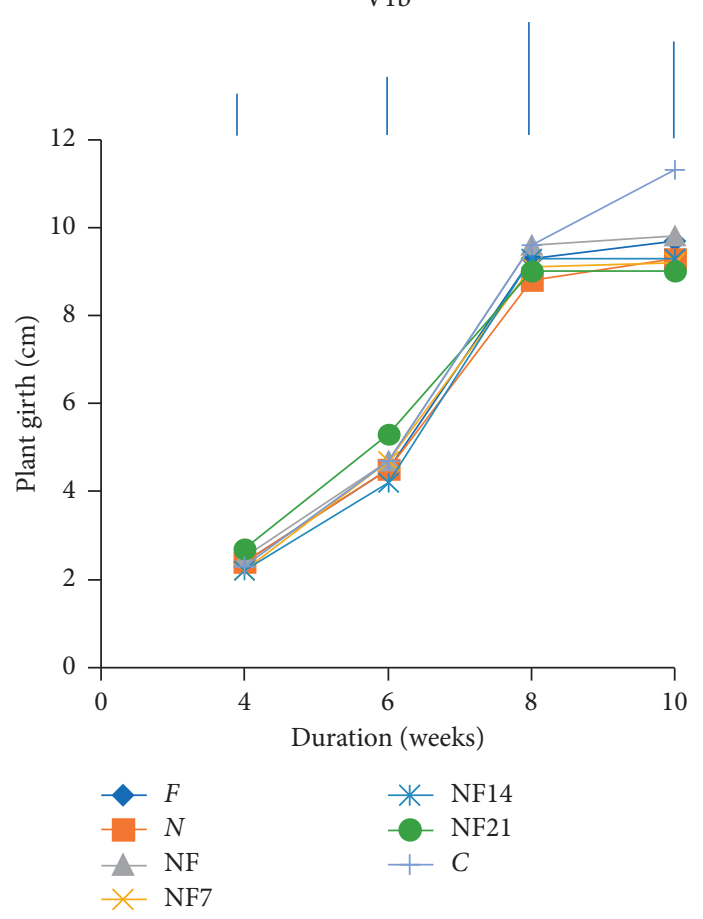

(b)

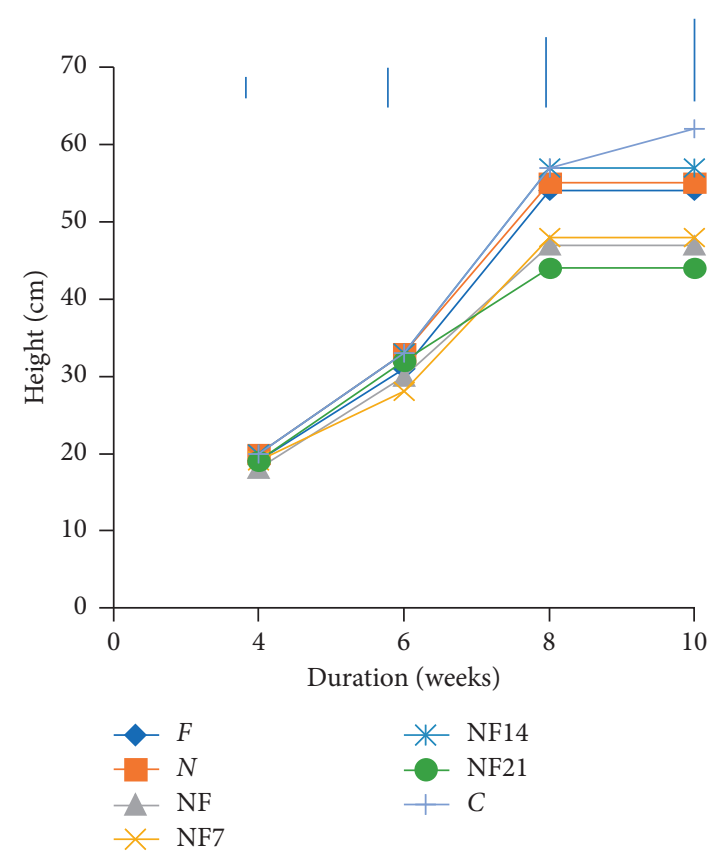

(d)

Figure 1: Continued. 


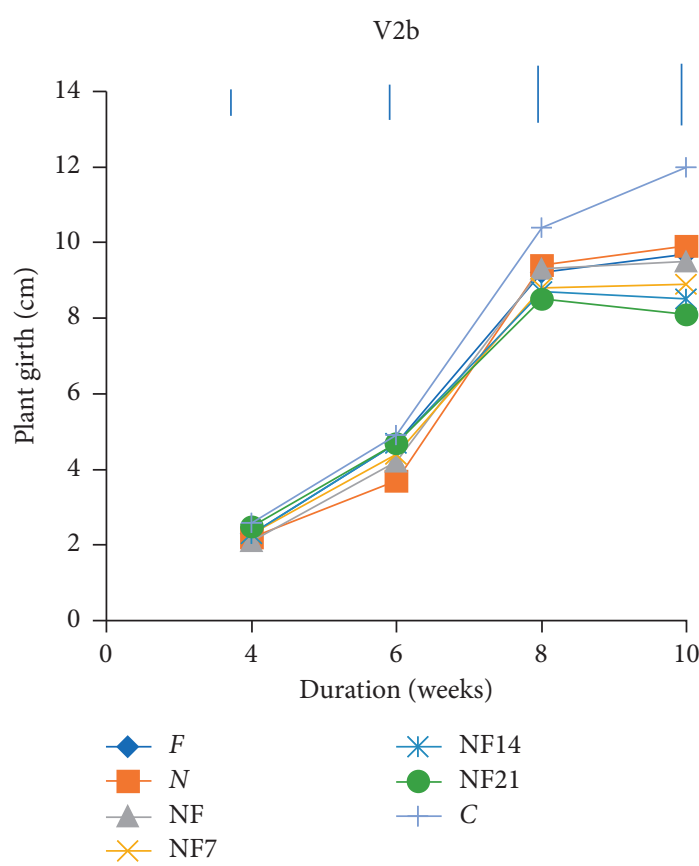

(e)



(f)

Figure 1: Plant height, girth, and chlorophyll contents of Essoumtem (V1a, V1b, and V1c) and Clemson spineless (V2a, V2b, and V2c) okra plants inoculated individually and simultaneously with Meloidogyne incognita and Fusarium oxysporum $\mathrm{f}$ sp. vasinfectum in pot experiment. $F$ =fungus alone; $N$ =nematode alone; $N F=$ nematode and fungus, simultaneously; NF7 = fungus 7 days after nematode inoculation; NF14 = fungus 14 days after nematode inoculation; NF21 = fungus 21 days after nematode inoculation; and $C=$ control (uninoculated).

There were significant differences $(P<0.05)$ among dry root weight treatments for both okra varieties. Clemson spineless plants inoculated with NF21 treatment showed the least dry root weight $(116 \mathrm{~g})$. Plants that received $F, N$, NF, NF7, and NF14 treatments did not significantly differ from each other. The highest dry root weight $(267 \mathrm{~g})$ was observed on plants in control plots.

The highest percentage reductions (85.2\% and 56.6\%) in dry root weight of okra were observed on both Essoumtem and Clemson spineless plants that received NF21 treatments, respectively. The least percentage reductions $(31.2 \%$ and 22.5\%) were observed on Essoumtem plants that received $\mathrm{NF}$ treatment and Clemson spineless plants that received NF7 treatments, respectively (Table 2).

3.1.4. Yield of "Essoumtem" and "Clemson Spineless" (Pot Experiment). Weight of pods was significantly affected by the pathogens (fungus and nematode) on both okra varieties. The highest percentage reductions (44.9\% and $48.3 \%)$ in weight of pods of okra were observed on Essoumtem plants and Clemson spineless plants, both inoculated with NF21 treatments. The least percentage reductions $(32.5 \%$ and 28.2\%) were observed on Essoumtem plants that received NF treatment and Clemson spineless plants that received $F$ treatment, respectively, with no percentage reduction on control plants (Table 3).

The highest yields $(1,575.0 \mathrm{~kg} / \mathrm{ha}$ and $1,816.7 \mathrm{~kg} / \mathrm{ha})$ were in Essoumtem and Clemson spineless plants in control plots. The least yields $(868.3 \mathrm{~kg} / \mathrm{ha}$ and $940 \mathrm{~kg} / \mathrm{ha})$ were observed in plants that received NF21 treatments for Essoumtem and Clemson spineless, respectively (Table 3).

3.1.5. Percentage Wilt Incidence on "Essoumten" and "Clemson Spineless" (Pot Experiment). There was significant increase $(P<0.05)$ in wilt incidence among treatments applied to Essoumtem okra plants. The highest disease incidence $(73 \%)$ was observed on plants that received NF21 treatment. The least incidence (0\%) was observed in plants that received $N$ and control treatments (Table 4$)$. There was also significant increase $(P<0.05)$ in wilt incidence among treatments applied to Clemson spineless okra plants. The highest disease incidence (82\%) was observed in plants that received NF21 treatment. The least incidence $(0 \%)$ was in plants that received $N$ and control treatments (Table 4).

\subsection{Field Experiment}

3.2.1. Mean Plant Height, Girth, and Chlorophyll Contents of "Essoumtem" and "Clemson Spineless" Plants Inoculated with Fusarium oxysporum in Field Experiment from Weeks 4 to 10. There were significant differences $(P<0.05)$ in plant height among various treatments applied to Essoumtem and Clemson spineless plants. Generally, plant heights increased from week 4 to 8 for Essoumtem plants (V1a); however, there was a decrease in plant height 8 weeks after planting (WAP) towards 10 WAP for plants that received F7, F14, and F21 treatments. The maximum plant height was in plants in control plots (Figure 2). Within Clemson spineless 
TABLE 1: Fresh and dry shoot weights for "Essoumtem" and "Clemson spineless" under various inoculations in pot experiment.

\begin{tabular}{|c|c|c|c|c|c|c|c|c|}
\hline \multirow{2}{*}{ Type of inoculation } & \multicolumn{2}{|c|}{ Fresh shoot weight $(\mathrm{g})$} & \multicolumn{2}{|c|}{ \% Reduction } & \multicolumn{2}{|c|}{ Dry shoot weight (g) } & \multicolumn{2}{|c|}{ \% Reduction } \\
\hline & $V 1$ & $V 2$ & $V 1$ & $V 2$ & $V 1$ & $V 2$ & $V 1$ & $V 2$ \\
\hline$F$ & $940.0 \mathrm{~b}^{*}$ & $1047.0 \mathrm{~b}$ & 39.5 & 17.8 & $597.0 \mathrm{ab}$ & $705.0 \mathrm{ab}$ & 50.7 & 27.5 \\
\hline$N$ & $1354.0 \mathrm{~b}$ & $858.0 \mathrm{~b}$ & 12.9 & 32.6 & $1119.0 \mathrm{~b}$ & $574.0 \mathrm{~b}$ & 7.5 & 41.0 \\
\hline NF & $1259.0 \mathrm{~b}$ & $857.0 \mathrm{~b}$ & 19.0 & 32.7 & $1036.0 \mathrm{~b}$ & $452.0 \mathrm{~b}$ & 14.4 & 53.5 \\
\hline NF7 & $1079.0 \mathrm{~b}$ & $964.0 \mathrm{~b}$ & 30.5 & 24.3 & $855.0 \mathrm{~b}$ & $661.0 \mathrm{~b}$ & 29.3 & 32.1 \\
\hline NF14 & $994.0 \mathrm{ab}$ & $748.0 \mathrm{ab}$ & 36.0 & 41.2 & $716.0 \mathrm{ab}$ & $518.0 \mathrm{ab}$ & 40.8 & 46.8 \\
\hline NF21 & $767.0 \mathrm{a}$ & $593.0 \mathrm{a}$ & 50.6 & 53.4 & $471.0 \mathrm{a}$ & $329.0 \mathrm{a}$ & 61.1 & 66.2 \\
\hline C & $1554.0 \mathrm{c}$ & $1273.0 \mathrm{c}$ & - & - & $1210.0 \mathrm{c}$ & $973.0 \mathrm{c}$ & - & - \\
\hline
\end{tabular}

$F=$ fungus alone; $N=$ nematode alone; $N F=$ nematode and fungus simultaneously; NF7 = fungus 7 days after nematode inoculation; NF14 = fungus 14 days after nematode inoculation; NF21 = fungus 21 days after nematode inoculation, and $C=$ control (uninoculated). $V 1=$ Essoumtem, $V 2=$ Clemson spineless.

${ }^{*}$ Followed by the same letter in a column are not significantly different at LSD $(P<0.05)$.

TABle 2: Fresh root weight and dry root weight for "Essoumtem" and "Clemson spineless" under various inoculations in pot experiment.

\begin{tabular}{lcccccrrr}
\hline \multirow{2}{*}{ Type of inoculation } & \multicolumn{2}{c}{ Fresh root weight $(\mathrm{g})$} & \multicolumn{2}{c}{ \% Reduction } & \multicolumn{2}{c}{ Dry root weight (g) } & \multicolumn{2}{c}{$\%$ reduction } \\
& $V 1$ & $V 2$ & $V 1$ & $V 2$ & $V 1$ & $V 2$ & $V 1$ \\
\hline$F$ & $506.0 \mathrm{ab} *$ & $503.0 \mathrm{ab}$ & 30.4 & 20.0 & $277.0 \mathrm{ab}$ & $145.0 \mathrm{ab}$ & 51.7 \\
$N$ & $531.0 \mathrm{ab}$ & $398.0 \mathrm{ab}$ & 27.0 & 36.6 & $276.0 \mathrm{ab}$ & $147.0 \mathrm{ab}$ & 51.8 & 44.4 \\
NF & $615.0 \mathrm{ab}$ & $349.0 \mathrm{ab}$ & 15.4 & 44.4 & $394.0 \mathrm{ab}$ & $141.0 \mathrm{ab}$ & 31.2 & 47.2 \\
NF7 & $597.0 \mathrm{ab}$ & $390.0 \mathrm{ab}$ & 17.9 & 37.9 & $312.0 \mathrm{ab}$ & $207.0 \mathrm{ab}$ & 45.5 & 22.5 \\
NF14 & $532.0 \mathrm{ab}$ & $311.0 \mathrm{ab}$ & 26.8 & 50.5 & $337.0 \mathrm{ab}$ & $150.0 \mathrm{ab}$ & 41.2 & 43.8 \\
NF21 & $221.0 \mathrm{a}$ & $300.0 \mathrm{a}$ & 69.6 & 52.2 & $85.0 \mathrm{a}$ & $116.0 \mathrm{a}$ & 85.2 & 56.6 \\
C & $727.0 \mathrm{~b}$ & $628.0 \mathrm{~b}$ & - & - & $573.0 \mathrm{~b}$ & $267.0 \mathrm{~b}$ & - & - \\
\hline
\end{tabular}

$F$ = fungus alone; $N=$ nematode alone; $\mathrm{NF}=$ nematode and fungus simultaneously; NF7 = fungus 7 days after nematode inoculation; NF14= fungus 14 days after nematode inoculation; NF21 = fungus 21 days after nematode inoculation, and $C=$ control (uninoculated). $V 1=$ Essoumtem, $V 2=C l e m s o n$ spineless. ${ }^{*}$ Followed by the same letter in a column are not significantly different at LSD $(P<0.05)$.

okra plants (V2a), the maximum plant height $(23.1 \mathrm{~cm})$ was observed in plant in control plots. The minimum plant height $(16.8 \mathrm{~cm})$ was observed in plants that received $F 21$ treatment (Figure 2).

Plant girth for both Essoumten (V1b) and Clemson spineless (V2b) okra varieties showed significant difference $(P<0.05)$ among the treatments. The least $(2.8 \mathrm{~cm})$ and highest $(3.5 \mathrm{~cm})$ plant girths at 10 WAP were observed in plants that received $F 7$ and $F 21$, and control treatments, respectively. The Clemson spineless plants within control plots had the highest plant girth $(2.9 \mathrm{~cm})$.

There were significant differences $(P<0.05)$ in chlorophyll content among the various treatments for Essoumtem okra plants (V1c). The lowest chlorophyll content (43.0 CCI) was observed in plants inoculated with $F 21$ treatment. The highest chlorophyll content (56.8 CCI) was recorded by uninoculated plants (Figure 2).

There were significant differences in chlorophyll content $(P<0.05)$ among different treatments on Clemson spineless (V2c). The lowest chlorophyll content (32.5 CCI) was observed in plants inoculated with F21 treatment. The highest chlorophyll content (45.6 CCI) was in okra plants in control plots (Figure 2).

3.2.2. Fresh and Dry Shoot Weights of "Essoumten" and "Clemson Spineless" (Field Experiment). There were significant differences $(P<0.05)$ in fresh and dry shoot weights among the treatments on both okra varieties, with the exception of fresh shoot weights for Essoumtem plants.
The highest percentage reductions $(57.2 \%$ and $8.1 \%)$ in fresh shoot weight of okra varieties were observed in Clemson spineless and Essoumtem plants that received F21 and F14 treatments, respectively. The minimum percentage reductions (1.1\% and 32.2\%) were observed on Essoumtem and Clemson spineless plants both inoculated with $F 7$ treatment (Table 5).

Within the dry shoot measurements, the highest percentage reductions $(57.4 \%$ and $47.3 \%)$ were observed in plants inoculated with F21 treatments for Essoumtem and Clemson spineless, respectively. The least percentage reductions (22.9\% and $18.3 \%)$ were, however, observed on Essoumtem and Clemson spineless plants that received $F 7$ treatments, respectively (Table 5).

3.2.3. Fresh and Dry Root Weights of "Essoumten" and "Clemson Spineless" (Field Experiments). There were significant differences $(P<0.05)$ in fresh and dry root weights of both okra varieties. However, significant differences did not exist among Essoumtem fresh root and Clemson spineless dry root weights (Table 6).

The highest percentage reductions (39.9\% and 56.4\%) among okra varieties were observed in plants inoculated with F21 treatments for Essoumtem and Clemson spineless plants, respectively.

Within the dry root measurements, the highest percentage reductions $(58.7 \%$ and $64.5 \%)$ were observed in plants inoculated with F21 treatments for Essoumtem and Clemson spineless plants, respectively (Table 6). 
TABLE 3: Weight of pods and yield for "Essoumtem" and "Clemson spineless" under various inoculations in pot experiment.

\begin{tabular}{|c|c|c|c|c|c|c|c|c|}
\hline \multirow{2}{*}{ Type of inoculation } & \multicolumn{2}{|c|}{ Weight of pods (g) } & \multicolumn{2}{|c|}{$\%$ Reduction } & \multicolumn{2}{|c|}{ Yield (kg/ha) } & \multicolumn{2}{|c|}{ \% Reduction } \\
\hline & $V 1$ & $V 2$ & $V 1$ & $V 2$ & $V 1$ & $V 2$ & $V 1$ & $V 2$ \\
\hline$F$ & $628.0 \mathrm{a}^{*}$ & $783.0 \mathrm{a}$ & 33.5 & 28.2 & $1.046 .7 \mathrm{a}$ & $1.305 .0 \mathrm{a}$ & 33.5 & 28.2 \\
\hline$N$ & $604.0 \mathrm{a}$ & $676.0 \mathrm{a}$ & 36.1 & 38.0 & $1.006 .7 \mathrm{a}$ & $1.126 .7 \mathrm{a}$ & 36.1 & 38.0 \\
\hline NF & $638.0 \mathrm{a}$ & $744.0 \mathrm{a}$ & 32.5 & 31.7 & $1.063 .3 \mathrm{a}$ & $1.240 .0 \mathrm{a}$ & 32.5 & 31.7 \\
\hline NF7 & $605.0 \mathrm{a}$ & $638.0 \mathrm{a}$ & 36.0 & 41.5 & $1.008 .3 \mathrm{a}$ & $1.063 .3 \mathrm{a}$ & 36.0 & 41.5 \\
\hline NF14 & $558.0 \mathrm{a}$ & $627.0 \mathrm{a}$ & 41.0 & 42.5 & $930.0 \mathrm{a}$ & $1.045 .0 \mathrm{a}$ & 41.0 & 42.5 \\
\hline NF21 & $521.0 \mathrm{a}$ & $564.0 \mathrm{a}$ & 44.9 & 48.3 & $868.3 \mathrm{a}$ & $940.0 \mathrm{a}$ & 44.9 & 48.3 \\
\hline$C$ & $945.0 \mathrm{~b}$ & $1.090 .0 \mathrm{~b}$ & - & - & $1.575 .0 \mathrm{~b}$ & $1.816 .7 \mathrm{~b}$ & - & - \\
\hline
\end{tabular}

$F=$ fungus alone; $N=$ nematode alone; NF= nematode and fungus simultaneously; NF7 = fungus 7 days after nematode inoculation; NF14= fungus 14 days after nematode inoculation; NF21 = fungus 21 days after nematode inoculation, and $C=$ control (uninoculated); $V 1=$ Essoumtem, $V 2=\mathrm{Clemson}$ spineless * Followed by the same letter in a column are not significantly different at LSD $(P<0.05)$.

TABLE 4: Percentage wilt incidence for "Essoumtem" and "Clemson spineless" under various inoculations in pot experiment.

\begin{tabular}{lcc}
\hline Type of inoculation & Essoumtem & Wilt incidence \\
& Clemson spineless \\
\hline F: fungus alone & 37.0 & 32.0 \\
N: nematode alone & 0.0 & 0.0 \\
NF: nematode and fungus inoculated simultaneously & 41.0 & 43.0 \\
NF7: fungus inoculated 7 days after nematode inoculation & 45.0 & 42.0 \\
NF14: fungus inoculated 14 days after nematode inoculation & 65.0 & 60.0 \\
NF21: fungus inoculated 21 days after nematode inoculation & 73.0 & 82.0 \\
C: control (uninoculated) & 0.0 & 0.00 \\
\hline
\end{tabular}

3.2.4. Yield of "Essoumten" and "Clemson Spineless" after Treatment Applications. There were significant differences among pod weights and yield among okra varieties. The highest yields $(269.0 \mathrm{~kg} / \mathrm{ha}$ and $185 \mathrm{~kg} / \mathrm{ha})$ were observed in Essoumtem and Clemson spineless plants in control plots (Table 7). Significant differences in yield, however, did not exist among Essoumtem plants that received the treatments $F 7, F 14$, and F21. The least yield ( $51.7 \mathrm{~kg} / \mathrm{ha})$ for Clemson spineless was in plants that received the treatment F21.

\subsubsection{Percentage Wilt Incidence of "Essoumten" and} "Clemson Spineless" in Pot Experiment. High wilt incidences, $73 \%$ and $82 \%$, were observed in both okra varieties that received NF21 treatment. Okra plants in control plots had the least wilt incidences (Figure 3). However, okra varieties that received $\mathrm{N}$ and control treatments have the least $(0 \%)$ wilt incidences for the varieties (Table 8 ).

3.2.6. Percentage Wilt Incidence of "Essoumten" and "Clemson Spineless" in Field Experiment. The uninoculated plants had the least $(0.0 \%)$ wilt incidences for both varieties. High wilt incidences (59.0\% and 65.0\%) were observed on Essoumtem and Clemson spineless plants that received F21 treatments, respectively (Table 9).

\section{Discussion}

In this study, the shorter plant heights $(43 \mathrm{~cm}$ and $44 \mathrm{~cm})$, smaller plant girths $(9 \mathrm{~cm}$ and $8.1 \mathrm{~cm})$, and lower chlorophyll contents (37 CCI and $32 \mathrm{CCI}$ ) in inoculated plants in pot experiments for "Essoumtem" and Clemson spineless okra plants, respectively, were due to root damage in the pot experiment reducing the ability of plants to take up water and minerals from the soil via the roots to aid in photosynthesis. In the field experiment, the shorter plant height $(15 \mathrm{~cm}$ and $17.1 \mathrm{~cm})$, smaller plant girth $(2.8 \mathrm{~cm}$ and $1.9 \mathrm{~cm})$, and lower chlorophyll contents (43 CCI and $32 \mathrm{CCI}$ ) in inoculated plants for "Essoumtem" and Clemson spineless okra plants, respectively, were also due to root damage. Growth and development of leaf tissue and chlorophyll contents are affected when there is inadequate supply of water, minerals, energy, and photosynthates [29]. Damage of roots of okra plants does not allow absorption of water and mineral from the soil thereby causing stunting. Wilting and stunting of plants occurs when nematode infestation is also prevalent [30].

In the current study, plants that received sequential treatments (NF7, NF14, and NF21) had higher reductions in their plant growth parameters, e. g., fresh shoot weight, dry shoot weight, fresh root weight, and dry root weight for "Essoumtem" and Clemson spineless okra varieties, respectively, in both pot and field experiments. In a previous glasshouse study, isolates of $M$. incognita and $F$. solani caused a severe reduction in tomato plants for shoot length (43.83\%), root length $(52.02 \%)$, fresh shoot $(52.81 \%)$, root weight $(60.99 \%)$, dry shoot $(57.75 \%)$, and root weights (67.96) compared to the plots that were not inoculated [31].

There were significant reductions in the weight of pods and yield after interaction between nematode and fungus on "Essoumtem" and Clemson spineless in both pot and field experiments. In the pot experiment, the weight of pods (521 $\mathrm{g}$ and $567 \mathrm{~g}$ ) and the yield (868 kg/ha and $940 \mathrm{~kg} / \mathrm{ha}$ ) were very low for plants that received F21 treatments in both "Essoumtem" and Clemson spineless varieties, 


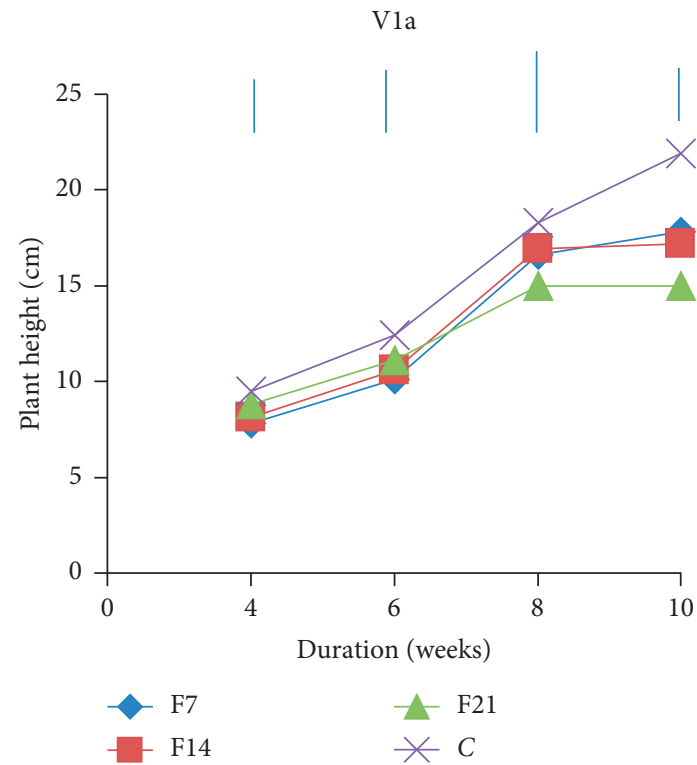

(a)

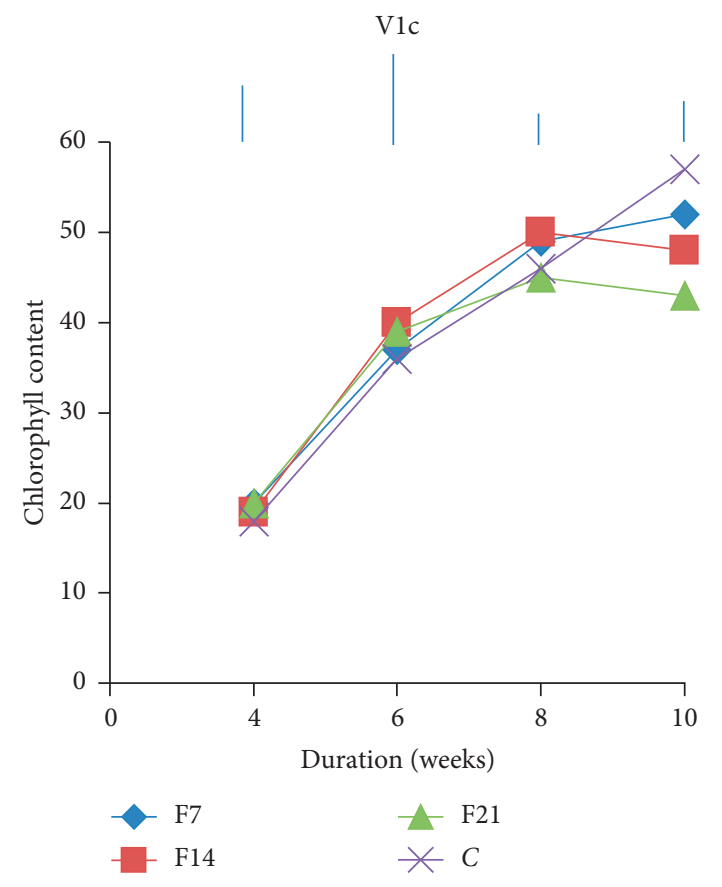

(c)

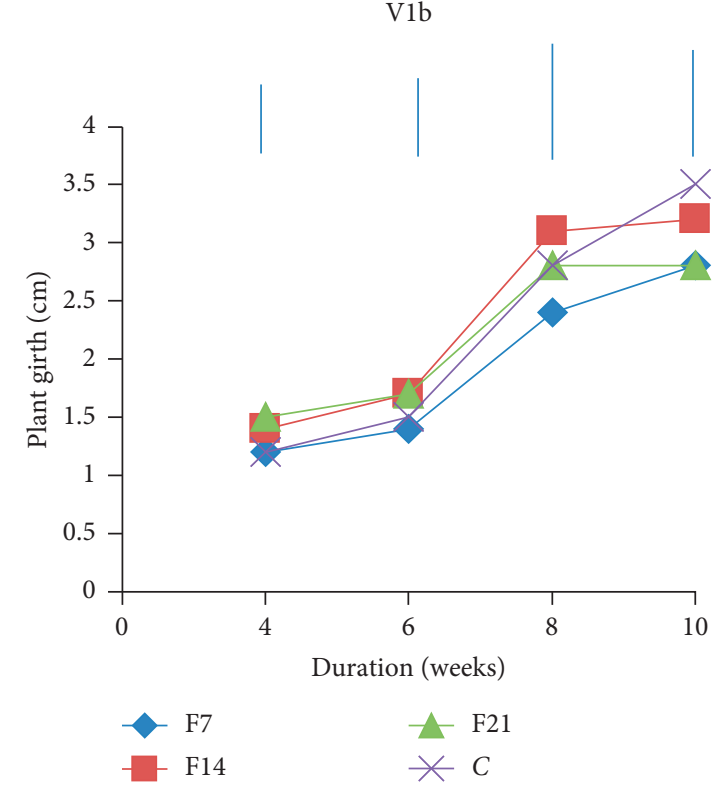

(b)

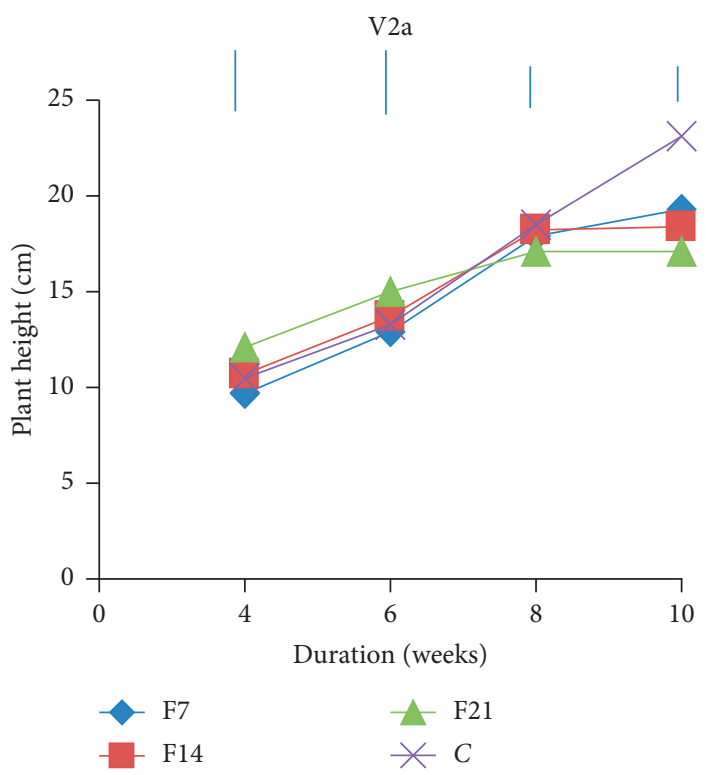

(d)

FIgURE 2: Continued. 


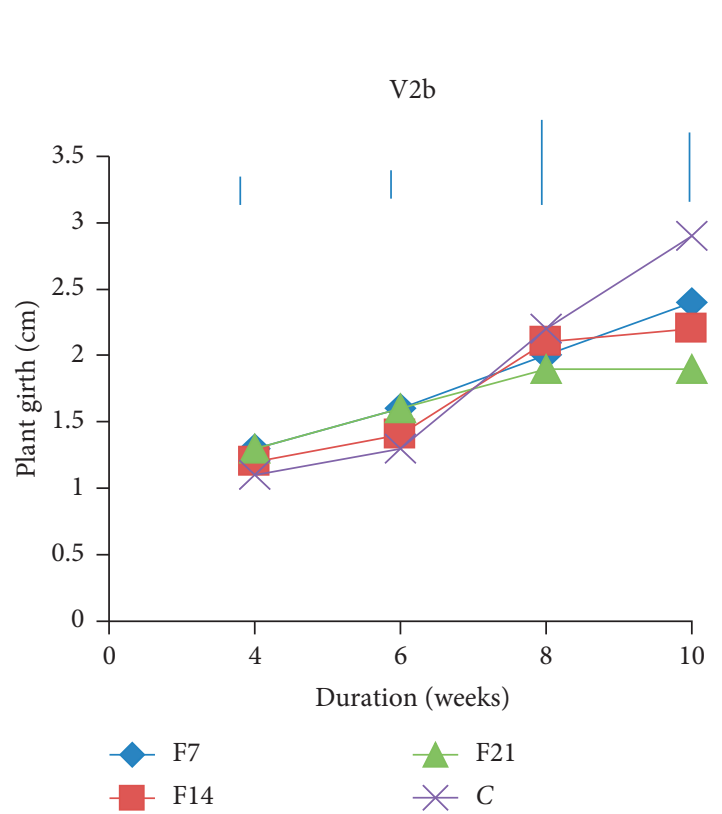

(e)

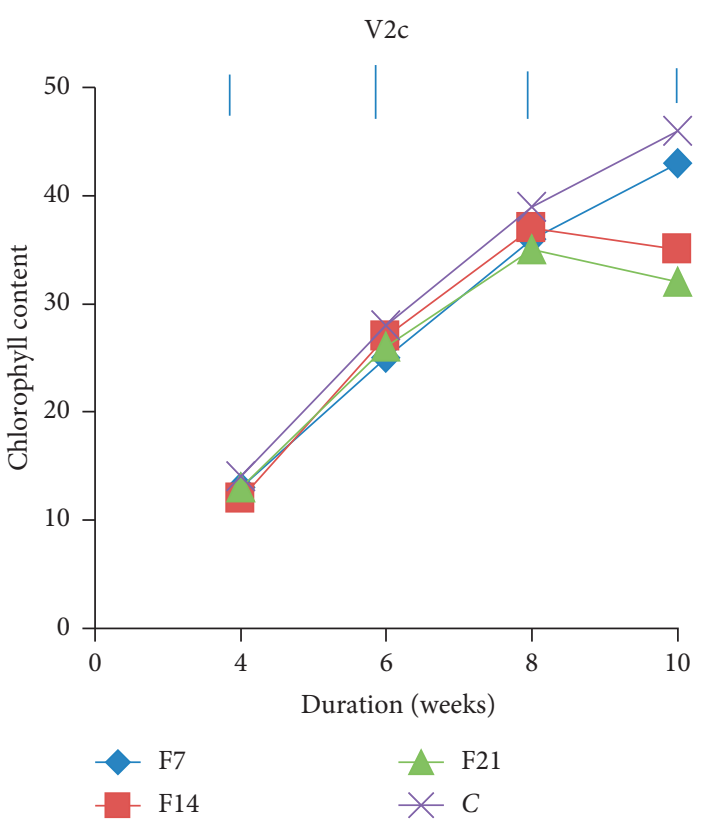

(f)

Figure 2: Plant height, girth, and chlorophyll content of Essoumtem V1a, V1b, and V1c and Clemson spineless V2a, V2b, and V2c okra plants inoculated individually and simultaneously with Meloidogyne incognita and Fusarium oxysporum $\mathrm{f}$ sp. vasinfectumon field. $F=$ fungus alone; $N=$ nematode alone; NF = nematode and fungus simultaneously; NF7 = fungus 7 days after nematode inoculation; NF14= fungus 14 days after nematode inoculation; NF21 = fungus 21 days after nematode inoculation; and $C=$ control (uninoculated).

TAвLE 5: Fresh and dry shoot weights for "Essoumtem" and "Clemson spineless" under four inoculations in field experimentation.

\begin{tabular}{lcccccccc}
\hline \multirow{2}{*}{ Type of inoculation } & \multicolumn{2}{c}{ Fresh shoot weight $(\mathrm{g})$} & \multicolumn{2}{c}{ \% Reduction } & \multicolumn{2}{c}{ Dry shoot weight (g) } & \multicolumn{2}{c}{ \% Reduction } \\
& $V 1$ & $V 2$ & $V 1$ & $V 2$ & $V 1$ & $V 2$ & $V 1$ & $V 2$ \\
\hline F7 & $103.5 \mathrm{a}^{*}$ & $33.3 \mathrm{ab}$ & 1.1 & 32.2 & $17.2 \mathrm{bc}$ & $7.6 \mathrm{~b}$ & 22.9 \\
$F 14$ & $96.2 \mathrm{a}$ & $29.7 \mathrm{a}$ & 8.1 & 39.5 & $11.8 \mathrm{ab}$ & $6.5 \mathrm{a}$ & 47.1 & 30.3 \\
$F 21$ & $98.6 \mathrm{a}$ & $21.0 \mathrm{a}$ & 5.8 & 57.2 & $9.5 \mathrm{a}$ & $4.9 \mathrm{a}$ & 57.4 & 47.3 \\
$C$ & $104.7 \mathrm{a}$ & $49.1 \mathrm{~b}$ & - & - & $22.3 \mathrm{c}$ & $9.3 \mathrm{c}$ & - & - \\
\hline
\end{tabular}

$F 7=$ fungus inoculated 7 days after seedling emergence, $F 14=$ fungus inoculated 14 days after seedling emergence, $F 21=$ fungus inoculated 21 days after seedling emergence, and $C=$ control (uninoculated); $V 1=$ Essoumtem and $V 2=$ Clemson spineless. ${ }^{*}$ Followed by the same letter in a column are not significantly different at LSD $(P<0.05)$.

TABLE 6: Fresh and dry root weights for "Essoumtem" and "Clemson spineless" under four inoculations in field experimentation.

\begin{tabular}{lcccccccc}
\hline \multirow{2}{*}{ Type of inoculation } & \multicolumn{2}{c}{ Fresh root weight $(\mathrm{g})$} & \multicolumn{2}{c}{ \% Reduction } & \multicolumn{2}{c}{ Dry root weight (g) } & \multicolumn{2}{c}{ \% Reduction } \\
& $V 1$ & $V 2$ & $V 1$ & $V 2$ & $V 1$ & $V 2$ & $V 1$ & $V 2$ \\
\hline F7 & $31.5 \mathrm{a}^{*}$ & $10.0 \mathrm{a}$ & 19.8 & 39.4 & $5.1 \mathrm{bc}$ & $2.5 \mathrm{a}$ & 19.0 \\
F14 & $28.9 \mathrm{a}$ & $8.9 \mathrm{a}$ & 26.5 & 46.1 & $3.9 \mathrm{ab}$ & $1.7 \mathrm{a}$ & 38.1 \\
F21 & $23.6 \mathrm{a}$ & $7.2 \mathrm{a}$ & 39.9 & 56.4 & $2.6 \mathrm{a}$ & $1.1 \mathrm{a}$ & 58.7 & 64.2 \\
$C$ & $39.3 \mathrm{a}$ & $16.5 \mathrm{~b}$ & - & - & $6.3 \mathrm{c}$ & $3.1 \mathrm{a}$ & - & - \\
\hline
\end{tabular}

$F 7=$ fungus inoculated 7 days after seedling emergence, $F 14=$ fungus inoculated 14 days after seedling emergence, $F 21=$ fungus inoculated 21 days after seedling emergence, and $C=$ control (uninoculated); $V 1=$ Essoumtem and $V 2=$ Clemson spineless. ${ }^{*}$ Followed by the same letter in a column are not significantly different at LSD $(P<0.05)$.

respectively. In the field experiments, weight of pods $(77.8 \mathrm{~g}$ and $30.4 \mathrm{~g})$ and the yield (130 kg/ha and $51 \mathrm{~kg} / \mathrm{ha})$ were very low for plants that received F21 treatments in both "Essoumtem" and Clemson spineless varieties, respectively. Nematodes are found to be serious pest of okra plant damaging plant stands thereby delaying the production of okra pods by almost $80 \%$ [32]. Reports show that infection of crops by Meloidogyne spp. causes severe growth impairment and yield losses [16,33-35]. The figures observed in the current study indicate that nematodes reduce the production of pods in okra plants, especially in the field where nematode population was high. The poor growth of leaves of plant consequently leads to decrease in yield $[15,36]$. 


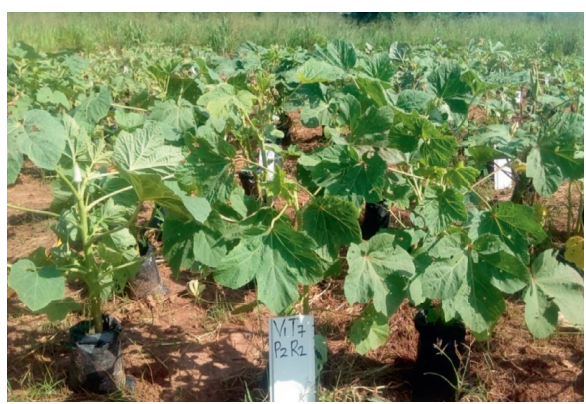

(a)

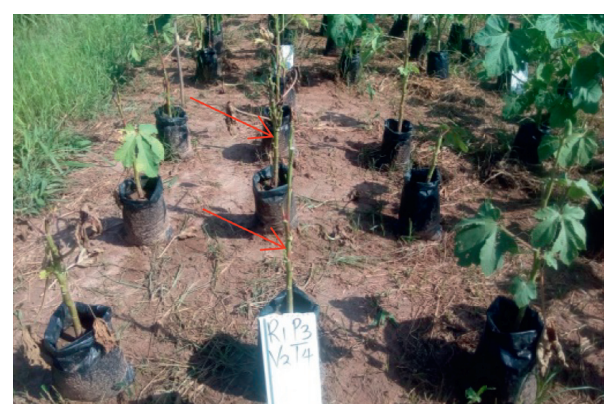

(b)

FIGURE 3: Healthy Essoumtem okra plants in potting bags (control) (a) and wilted clemson spineless plants in potting bags that received the treatment NF7 (b) and red arrows show some wilted plants.

TABLE 7: Weight of pods and yield of "Essoumtem" and "Clemson spineless" inoculated serially with Fusarium oxysporum $\mathrm{f}$ sp. vasinfectum in field experiment.

\begin{tabular}{lcccccrrr}
\hline \multirow{2}{*}{ Type of inoculation } & \multicolumn{2}{c}{ Weight of pods $(\mathrm{g})$} & \multicolumn{2}{c}{ \% Reduction } & \multicolumn{3}{c}{ Yield (kg/ha) } & \multicolumn{2}{c}{ \% Reduction } \\
& $V 1$ & $V 2$ & $V 1$ & $V 2$ & $V 1$ & $V 2$ & $V 1$ & $V 2$ \\
\hline$F 7$ & $96.1 \mathrm{a}^{*}$ & $75.9 \mathrm{ab}$ & 40.5 & 31.7 & $160.0 \mathrm{a}$ & $127.0 \mathrm{ab}$ & 40.5 \\
$F 14$ & $88.3 \mathrm{a}$ & $71.4 \mathrm{ab}$ & 45.3 & 35.7 & $147.0 \mathrm{a}$ & $119.0 \mathrm{ab}$ & 45.4 \\
$F 21$ & $77.8 \mathrm{a}$ & $30.4 \mathrm{a}$ & 51.8 & 72.6 & $130.0 \mathrm{a}$ & $51.0 \mathrm{a}$ & 51.7 & 72.4 \\
$C$ & $161.4 \mathrm{~b}$ & $111.1 \mathrm{~b}$ & - & - & $269.0 \mathrm{~b}$ & $185.0 \mathrm{~b}$ & - & - \\
\hline
\end{tabular}

$F 7=$ fungus inoculated 7 days after seedling emergence, $F 14=$ fungus inoculated 14 days after seedling emergence, $F 21=$ fungus inoculated 21 days after seedling emergence, $V 1=$ Essoumtem, and $V 2=$ Clemson spineless. ${ }^{*}$ Followed by the same letter in a column are not significantly different at LSD $(P<0.05)$.

Table 8: Percentage wilt incidence for "Essoumtem" and "Clemson spineless" under various inoculations in pot experiment.

\begin{tabular}{lcc}
\hline Type of inoculation & Essoumtem & \% Wilt incidence \\
& Clemson spineless \\
\hline F: fungus alone & 37.0 & 32.0 \\
N: nematode alone & 0.0 & 0.0 \\
NF: nematode and fungus inoculated simultaneously & 41.0 & 43.0 \\
NF7: fungus inoculated 7 days after nematode inoculation & 45.0 & 42.0 \\
NF14: fungus inoculated 14 days after nematode inoculation & 65.0 & 60.0 \\
NF21: fungus inoculated 21 days after nematode inoculation & 73.0 & 82.0 \\
C: control (uninoculated) & 0.0 & \\
\hline
\end{tabular}

TABle 9: Percentage wilt incidence for "essoumten" and "clemson spineless" under various inoculations in field experiment.

\begin{tabular}{lcc}
\hline Type of inoculation & Essoumtem & \% Wilt incidence \\
& Clemson spineless \\
\hline F7: fungus inoculated 7 days after seedling emergence & 12.0 & 12.0 \\
F14: fungus inoculated 14 days after seedling emergence & 23.0 & 28.0 \\
F21: fungus inoculated 21 days after seedling emergence & 59.0 & 65.0 \\
C: uninoculated (control) & 0.0 & 0.0 \\
\hline
\end{tabular}

The severity of root rot caused by F. oxysporum increased in the presence of $M$. incognita. Severity of the root rot disease was more prominent when the inoculation by $M$. incognita preceded the $F$. oxysporum by three weeks on "Essoumtem" and Clemson spineless in both pot and field experiments. Severe plant damage $\left(1+1^{>} 2\right)$ was realized when both pathogens were concomitantly or simultaneously inoculated. Specific fungi and other plant pathogens interact to form disease complexes [37]. In the presence of root-knot nematode, Rhizoctonia root rot was more severe. Root-rot disease complex, caused by $R$. solani and $M$. incognita, has been reported when root-knot nematode is present on okra and chilli [38, 39]. In this study, concomitant and sequential infection of Meloidogyne incognita and $F$. oxysporum resulted in more damages than the individual infection of the two pathogens on both "Essoumtem" and Clemson spineless. 


\section{Conclusion}

This study revealed that plant height, plant girth, chlorophyll content, fresh and dry shoot weights, and fresh and dry root weights were drastically reduced when nematode $(M$. incognita) and fungus (F. oxysporum f. sp. vasinfectum) were simultaneously inoculated on both "Essoumtem" and Clemson spineless, than when they were inoculated on the plants individually.

Serial and simultaneous inoculation of $M$. incognita and F. oxysporum f. sp. vasinfectum increased wilt incidence on "Essoumtem" and Clemson spineless in both pot and field trials compared to plants in control plots. The inoculation of M. incognita 21 days prior to F. oxysporum f. sp. vasinfectum resulted in the most severe wilt incidences in the two okra varieties ("Essoumtem" and Clemson spineless).

\section{Data Availability}

All data have been analyzed and incorporated into the manuscript as tables and figures.

\section{Conflicts of Interest}

The authors declare that there are no conflicts of interest regarding the publication of this article.

\section{References}

[1] A. Naveed, A. A. Khan, and I. A. Khan, "Generation mean analysis of water stress tolerance in okra (Abelmoschus esculentus L.)," Pakistan Journal of Botany, vol. 41, pp. 195-205, 2009.

[2] O. J. Oyelade, B. I. O. Ade-Omowaye, and V. F. Adeomi, "Influence of variety on protein, fat contents, and some physical characteristics of okra seeds," Journal of Food Engineering, vol. 57, no. 2, pp. 111-114, 2003.

[3] C. D. András, B. Simándi, F. Örsi et al., "Supercritical carbon dioxide extraction of okra (Hibiscus esculentus L) seeds," Journal of the Science of Food and Agriculture, vol. 85, no. 8, pp. 1415-1419, 2005.

[4] M. Saifullah and M. G. Rabbani, "Evaluation and characterization of okra (Abelmoschusesculentus L. Moench.) genotypes," SAARC Journal of Agriculture, vol. 7, pp. 92-99, 2009.

[5] S. E. Aladele, O. J. Ariyo, and R. Lapena, "Genetic relationships among West African okra (Abelmoschus caillei) and Asian genotypes (Abelmoschus esculentus L) using RAPD," African Journal of Biotechnology, vol. 7, pp. 1426-1431, 2008.

[6] Food and Agriculture Organization of the United Nations, Statistics Division (FAOSTAT), Food and Agriculture Data, 2018, http://www.fao.org/faostat/en/\#data/QC.

[7] O. K. Owolarafe and H. O. Shotonde, "Some physical properties of fresh okro fruit," Journal of Food Engineering, vol. 63, no. 3, pp. 299-302, 2004.

[8] C. Gopalan, S. B. V. Rama, and S. Balasubramanian, Nutritive Value of Indian Foods, Nutritive Institute of Nutrition (NIN), ICMR, Hyderabad, India, 2007.

[9] P. Arapitsas, "Identification and quantification of polyphenolic compounds from okra seeds and skins," Food Chemistry, vol. 110, no. 4, pp. 1041-1045, 2008.

[10] S. Dilruba, M. Hasanuzzaman, R. Karim, and K. Nahar, "Yield response of okra to different sowing time and application of growth hormones," Journal of Horticulture Science and Ornamental Plants, vol. 1, no. 1, pp. 10-14, 2009.

[11] S. Benchasri, "Okra (Abelmoschus esculentus (L.) Moench), as a valuable vegetable of the world," Field Vegetable Crop Research, vol. 49, no. 1, pp. 105-112, 2012.

[12] H. U. Khan, T. Mukhtar, and R. Ahmad, "Geographical distribution of root-knot nematodes (Meloidogynespp.) in the Punjab province of Pakistan," Pakistan Journal of Nematology, vol. 23, pp. 133-140, 2005.

[13] S. A. Anwar, A. Zia, M. Hussain, and M. Kamran, "Host suitability of selected plants to Meloidogyne incognita in the Punjab, Pakistan," International Journal of Nematology, vol. 17, pp. 144-150, 2007.

[14] M. A. Hussain, T. Mukhtar, M. Z. Kayani, M. N. Aslam, and M. I. Haque, "A survey of okra (Abelmoschus esculentus) in the Punjab province of Pakistan for the determination of prevalence, incidence and severity of root-knot disease caused by Meloidogyne spp," Pakistan Journal of Botany, vol. 44, pp. 2071-2075, 2012.

[15] M. A. Hussain, T. Mukhtar, and M. Z. Kayani, "Reproduction of Meloidogyne incognita on resistant and susceptible okra cultivars," Pakistan Journal of Agricultural Sciences, vol. 53, no. 2, pp. 371-375, 2016.

[16] M. Z. Kayani, T. Mukhtar, M. A. Hussain, and M. I. Ul-Haque, "Infestation assessment of root-knot nematodes (Meloidogyne spp.) associated with cucumber in the Pothowar region of Pakistan," Crop Protection, vol. 47, pp. 49-54, 2013.

[17] K. N. Ntidi, H. Fourie, and M. Daneel, "Greenhouse and field evaluations of commonly occurring weed species for their host suitability to Meloidogyne species field evaluations of commonly occurring weed species for their host suitability to Meloidogyne spp," International Journal of Pest Management, vol. 62, no. 1, pp. 11-19, 2016.

[18] L. H. Shigueoka, G. H. Sera, T. Sera et al., "Reaction of Arabica coffee progenies derivative from Icatu to Meloidogyne paranaensis," Bragantia, vol. 75, no. 2, pp. 193-198, 2016.

[19] M. U. Shahbaz, T. Mukhtar, M. I. Haque, and N. Begum, "Biochemical and serological characterization of Ralstonia solanacearum associated with chilli seeds from Pakinstan," International Journal of Agriculture and Biology, vol. 17, pp. 31-40, 2015.

[20] E. Cia and C. L. Salgado, "Doenças do algodoeiro (Gossypium spp.)," in Manual de Fitopatologia: Doenças das plantascultivadas, H. Kimati, L. Amorim, A. Bergamin Filho, L. E. A. Camargo, and J. A. M. Rezende, Eds., pp. 33-48, Agronômica Ceres, São Paulo, Brazil, 3 edition, 1997.

[21] G. S. Abawi and K. R. Barker, "Effects of cultivar, soil temperature, and population levels of Meloidogyne incognitaon root necrosis and Fusarium wilt of tomatoes," Phytopathology, vol. 74, no. 4, pp. 433-438, 1984.

[22] M. A. Back, P. P. J. Haydock, and P. Jenkinson, "Disease complexes involving plant parasitic nematodes and soilborne pathogens," Plant Pathology, vol. 51, no. 6, pp. 683697, 2002.

[23] P. Castillo, J. A. Navas-Cortés, D. Gomar-Tinoco, M. Di Vito, and R. M. Jiménez-Díaz, "Interactions between Meloidogyne artiellia, the cereal and legume root-knot nematode, and Fusarium oxysporum f. sp. ciceris race 5 in chickpea," Phytopathology, vol. 93, no. 12, pp. 1513-1523, 2003.

[24] A. A. Mokbel, I. K. A. Ibrahim, M. R. A. Shehata, and M. A. M. El-Saedy, "Interaction between certain root rot disease fungi and root-knot nematode Meloidogyne incognita on sunflower plants," Egyptian Journal of Phytopathology, vol. 35, pp. 1-11, 2007. 
[25] R. S. Hussey and K. R. Barker, "A comparison of methods of collecting inocula of Meloidogyne spp. including a new technique," Plant Disease Report, vol. 57, pp. 1025-1028, 1973.

[26] C. Booth, The Genus Fusarium, Commonwealth Mycological Institute, Kew, UK, 1971.

[27] Y. L. Nene, J. Kannaiyan, and M. V. Reddy, Resistance Screening Techniques for Pigeon Peas disease. Information Bulletin No. 9, ICRISAT, Patancheru, India, 1981.

[28] VSN International Ltd, Genstat 12th Edition for Windows, VSN Int. Ltd. UK, Hemel Hempstead, UK, 2009.

[29] Safiuddin and S. Shahab, "Interactive effect of root-knot nematode, Meloidogyne incognita and root-rot fungus, Rhizoctonia solani, on okra (Abelmoschus esculentus L.)," Archives of Phytopathology and Plant Protection, vol. 45, no. 6, pp. 660-666, 2012.

[30] T. C. William and A. D. Robert, Managing Nematodes for a Non-Commercial Vegetable Garden, pp. 12-17, US Department of Agriculture, Cooperative Extension service, University of Florida A and M University Cooperative Extension Programs and Boards of Country Commissioners Cooperating, Gainesville, FL, USA, 2007.

[31] M. A. Ganaie and T. A. Khan, "Studies on the interactive effect of Meloidogyne incognita and Fusarium solani on Lycopersicon esculentum, mill," International Journal of Botany, vol. 7, no. 2, pp. 205-208, 2011.

[32] B. Bolles and L. Johnson, Nematode Damage of Okra, University of Florida IFAS Extention, Gainesville, FL, USA, 2012.

[33] M. A. Hussain, T. Mukhtar, and M. Z. Kayani, "Assessment of the damage caused by Meloidogyne incognita on okra," Journal of Animal and Plant Science, vol. 21, no. 4, pp. 857861, 2011.

[34] T. Mukhtar, M. Z. Kayani, and M. A. Hussain, "Response of selected cucumber cultivars to Meloidogyne incognita," Crop Protection, vol. 44, pp. 13-17, 2013.

[35] A. F. Barros, R. D. L. Oliveira, I. M. Lima, R. R. Coutinho, A. O. Ferreira, and A. Costa, Root-Knot Nematodes, a Growing Problem for Conilon Coffee in Espírito Santostate, Brazil, Elsevier Ltd. Crop Prot., Amsterdam, Netherlands, 2014, http://www.elsevier.com/locate/cropro.

[36] M. Z. Kayani, T. Mukhtar, and M. A. Hussain, "Effects of southern root knot nematode population densities and plant age on growth and yield parameters of cucumber," Crop Protection, vol. 92, pp. 207-212, 2017.

[37] N. Begum, M. I. Haque, T. Mukhtar, S. M. Naqvi, and J. F. Wang, "Status of bacterial wilt caused by Ralstonia solanacearum in Pakistan," Pakistan Journal of Phytopathology, vol. 24, pp. 11-20, 2012.

[38] B. Bhagawati, B. C. Das, and A. K. Sinha, "Interaction of Meloidogyne incognita and Rhizoctonia solani on okra," Annals of Plant Protection Sciences, vol. 1, pp. 533-535, 2007.

[39] S. Abuzar, "Antagonistic effects of some fluorescent Pseudomonas strains against root-rot fungi (Rhizoctonia solani and Fusarium oxysporum) and root-knot nematodes (Meloidogyne incognita) on chili (Capsicum annum)," World Applied Science Journal, vol. 27, pp. 1455-1460, 2013. 